\title{
Yvan Farron, Pierre Michon, la grâce par les œuvres
}

\section{Stephane Chaudier}

\section{(2) OpenEdition}

\section{Journals}

\section{Édition électronique}

URL : http://journals.openedition.org/studifrancesi/35266

DOI : 10.4000/studifrancesi.35266

ISSN : 2427-5856

Éditeur

Rosenberg \& Sellier

\section{Édition imprimée}

Date de publication : 1 novembre 2005

Pagination : 453-454

ISSN : 0039-2944

\section{Référence électronique}

Stephane Chaudier, "Yvan Farron, Pierre Michon, la grâce par les œuvres », Studi Francesi [En ligne], 146 (XLIX | II) | 2005, mis en ligne le 30 novembre 2015, consulté le 19 avril 2021. URL : http://

journals.openedition.org/studifrancesi/35266 ; DOI : https://doi.org/10.4000/studifrancesi.35266

Ce document a été généré automatiquement le 19 avril 2021.

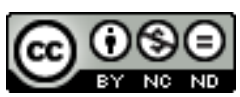

Studi Francesi è distribuita con Licenza Creative Commons Attribuzione - Non commerciale - Non opere derivate 4.0 Internazionale. 


\title{
Yvan Farron, Pierre Michon, la grâce par les œuvres
}

\author{
Stephane Chaudier
}

\section{RÉFÉRENCE}

YVAN FARRON, Pierre Michon, la grâce par les œuvres, Genève, éditions Zoé, collection

«Écrivains», 2004, pp. 178.

1 Sans naïveté aucune, Michon use de formes et de notions traditionnelles pour interroger l'acte créateur, sa genèse et sa nécessité. La littérature promet un salut qui ne vient pas. Source et expression de toutes les angoisses, ce ratage est l'objet privilégié de sa poétique; il trouve son origine biographique dans la honte liée à l'absence du père.

2 La première partie analyse l'œuvre comme carrefour de genres: romans, récits, essais critiques, biographies teintées d'autobiographie. Fiction et réalité, savoirs et fantasmes se mêlent. La seconde partie décrit les tensions fondatrices de l'œuvre: hantée par le prestige esthétique de l'autoréférence, très critique à l'égard de toute possibilité d'échange, l'œuvre n'en est pas moins hyperboliquement «adressée» à son destinataire. Étrangère et familière, la langue littéraire charrie la honte ineffaçable, indicible, mais aussi le réseau des belles citations et des métaphores sublimes, en particulier religieuses.

3 Cette rhétorique vise à reconstruire la figure du père, seule apte à permettre un rapport symbolique et non plus fusionnel avec la mère, seule apte aussi à légitimer la conquête de l'auctoritas littéraire (troisième partie). L'écriture peut ainsi recueillir des désirs contradictoires: aspiration quasi mystique mais aussi féroce volonté de puissance (quatrième et dernière partie). Se sachant ambivalente, l'œuvre de Michon exalte le suprême pouvoir des signes (représenter l'infini) mais dénonce aussi leur misère. C'est pourquoi aucune mythologie de l'art ne parvient à délivrer l'auteur de cette Présence dont l'absence le hante et l'inspire. Elle prend dans son œuvre tous les visages, celui de 
Dieu, celui du Livre mallarméen, mais aussi celui de la petite sœur morte avant même d'avoir parlé. 